УДК 656.21.02.001.6(07)

Канд. техн. наук К.В. Крячко,

О.М. Шалімова, С.В. Кабанець,

\title{
ТЕХНІЧНЕ ЗАБЕЗПЕЧЕННЯ НЕОБХІДНОЇ ПРОПУСКНОЇ СПРОМОЖНОСТІ ВНУТРІШНЬОВУЗЛОВИХ ХОДІВ
}

\author{
Представив д-р техн. наук, професор В.М. Запара
}

Вступ та актуальність проблеми. Залізничні вузли - це дуже складні системи, що розташовані на перехрещенні або злитті трьох та більше магістральних ліній i включають до свого складу, як правило, декілька станцій, з'єднаних внутрішньовузловими ходами, розв'язки на підходах та всередині вузла, обхідні колії, необхідні сполучення між промисловими підприємствами і магістральними роздільними пунктами.

В Україні нараховується близько 150 залізничних вузлів різних типів, 3 яких понад $70 \%$ складають вузли 3 однією об'єднаною станцією, яка не завжди навіть $\epsilon$ технічною, але виконує в повних обсягах пасажирську, технічну, сортувальну та вантажну роботу. Пропускна спроможність таких вузлів визначається згідно 3 Інструкцією [1] і не повинна бути меншою, ніж пропускна спроможність примикаючих до них підходів.

Серед інших залізничних вузлів майже дві третини складають вузли 3 послідовним розташуванням основних станцій пасажирських (ПС) i сортувальних (СС), пропускна спроможність яких залежить, в першу чергу, від кількості головних колій у межах вузла та їх взаємного розташування відносно цих станцій.

Протягом 18 років незалежності України довжина залізниць скоротилась майже на 2 тис. км; у зв'язку із зменшенням обсягів руху поїздів, була ремонтована частина не тільки станційних, але i головних колій на перегонах та в межах залізничних вузлів. Незважаючи на наявність інструктивних вказівок щодо розрахунку необхідної пропускної спроможності, на даний час не існує чіткої типової методики визначення кількості головних колій на внутрішньовузлових ходах, тому дана проблема $\epsilon$ актуальною при будь-яких обсягах руху поїздів.

Аналіз досліджень і публікацій. Значний внесок у теорію розрахунку технічного забезпечення необхідної пропускної спроможності внутрішньовузлових ходів зробили такі вчені: Земблінов С.В., Скалов К.Ю., Правдін М.В., Акулінічев В.М.

В результаті проведеного аналізу було встановлено, що в сучасних умовах дане питання вимагає додаткових досліджень. 
Визначення мети та задачі дослідження. Основною задачею $\epsilon$ визначення технічного забезпечення необхідної пропускної спроможності внутрішньовузлових ходів 3 метою організації стабільної роботи залізничних вузлів і примикаючих залізничних ліній.

Основний матеріал досліджень. Згідно 3 [2], число головних колій визначається від коефіцієнта заповнення пропускної спроможності:

$$
\mathrm{K}_{\text {зпс }}=N_{\text {ппс }} / n_{\text {Hпc }} \text {, }
$$

де $N_{n n c}, n_{\text {нис }}$ потрібна та наявна пропускна спроможність головних колій, поїзд/доб.

Потрібна пропускна спроможність має забезпечувати пропускання заданого числа поїздів різних категорій на розрахункові терміни експлуатації 3 урахуванням необхідного резерву.

Оскільки розв'язки підходів до залізничного вузла, відповідно до вимог [3], з урахуванням можливого їх розвитку, повинні проектуватися на п'ятий рік експлуатації, то такий же термін має встановлюватися і при визначенні потрібної пропускної спроможності головних колій у межах вузла. Розрахункове значення $N_{n n c}$ має відрізнятися від максимального на величину резерву (арез), що враховує технологічні перерви для утримання i ремонту пристроїв та споруд, а також резерв для забезпечення внутрішньодобових коливань обсягів руху поїздів. При проектуванні одноколійних ліній $\quad \alpha_{\text {рез }}=0,2 ;$ а при спорудженні двоколійних ліній, других головних колій та під'їзних колій $\alpha_{\text {pез }}=0,15$.

$N_{\text {пाт }}=\left(1-\alpha_{\text {pes }}\right) N_{\mathrm{B}}+\sum_{i=1}^{\mathrm{K}} E_{\mathrm{i}} N_{\mathrm{i}}$,

де $N_{6}-$ кількість вантажних поїздів розрахункового року експлуатації (визначається для кожного напрямку окремо), поїзд;
$N_{i}$ - кількість поїздів різних категорій, які відповідно до організації їх руху або швидкості руху знімають з графіка руху певну кількість вантажних поїздів, поїзд;

$E_{i}-$ коефіцієнт зняття вантажних поїздів 3 графіка руху поїздами інших категорій (пасажирськими, збірними, прискореними та ін.).

Залежно від різних факторів Еi набуває відповідних значень, які рекомендується визначати за формулами, згідно 3 [1], але для попередніх розрахунків можна використовувати такі середні значення:

1. Для одноколійних (через дріб - для двоколійних) дільниць, обладнаних автоматичним блокуванням або диспетчерською централізацією, $-\mathrm{E}_{\text {пс }}=1,4 / 1,8 ; \mathrm{E}_{\text {прм }}=1,5 / 1,6$; $\mathrm{E}_{\text {прc }}^{\mathrm{B}}=2,2 / 2,4 ; \mathrm{E}_{\text {mpc }}^{\mathrm{mi}}=2,6 / 3,0 ; \mathrm{E}_{\text {зб}}=2,8 / 3,2$.

2. Те ж для дільниць, обладнаних напівавтоматичним блокуванням, $\mathrm{E}_{\text {пс }}=1,3 / 1,4 ; \quad \mathrm{E}_{\text {прм }}=1,4 / 1,5 ; \quad \mathrm{E}_{\text {прс }}^{\mathrm{B}}=2,0 / 2,2 ;$ $\mathrm{E}_{\text {прс }}^{\text {ni }}=2,5 / 2,8 ; \quad \mathrm{E}_{\text {зб }}=2,6 / 2,9 \quad$ (значення наведені відповідно для приміських, пасажирських, прискорених вантажних, прискорених або швидких пасажирських та збірних поїздів).

Наявну пропускну спроможність також слід визначати за формулами [1], але середне значення можна прийняти:

1. Для одноколійних дільниць $\mathrm{n}_{\text {нпс }}=30$ поїздів на добу.

2. Для двоколійних дільниць, обладнаних напівавтоматичним блокуванням, 72 поїзди на добу, автоматичним блокуванням тризначним - 120 , чотиризначним 160 , частотним - 240 .

Для визначення $N_{n n c}$ слід розглядати шість розрахункових схем розташування основних станцій i головних колій $\mathrm{y}$ залізничному вузлі (див. рисунок). 
a)

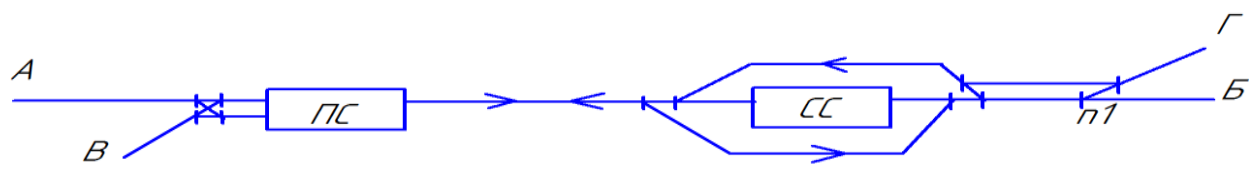

b)

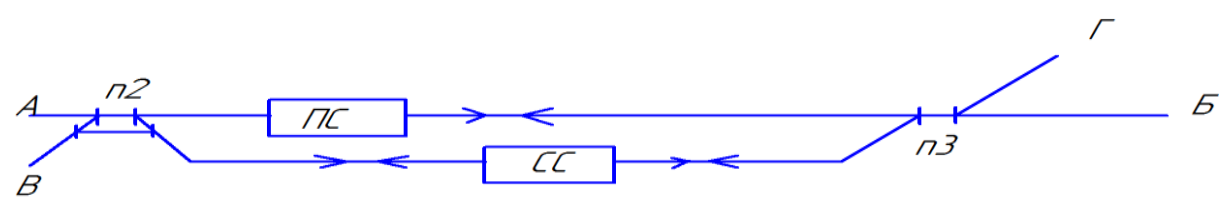

B)

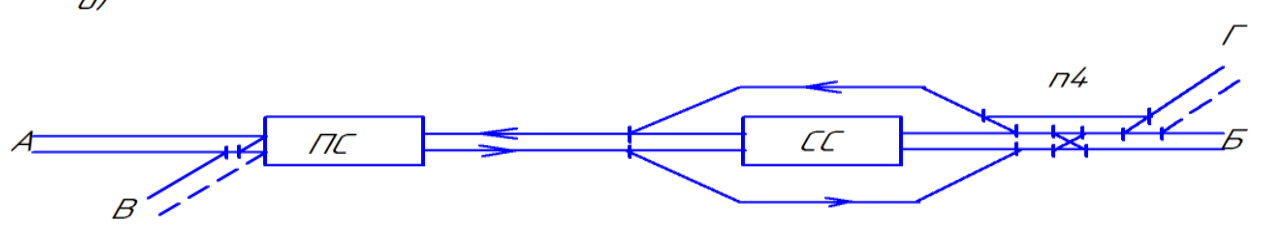

z)
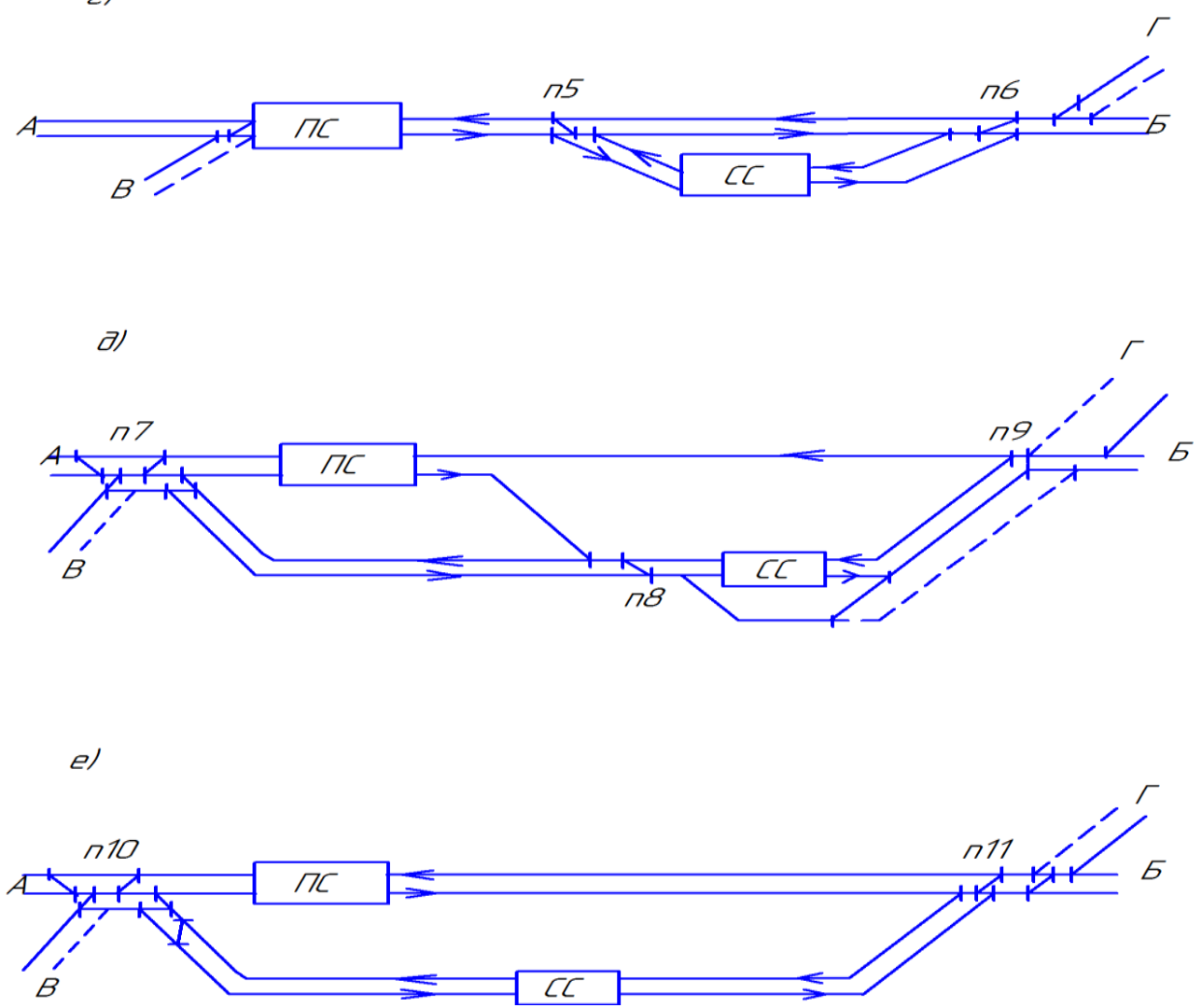

Рис. Розрахункові схеми для визначення потрібної пропускної спроможності внутрішньовузлових ходів 
Якщо станції розташовані за схемами 1a, 1в, то:

$$
\begin{aligned}
N_{\text {ппс }}= & \left(1-\alpha_{p e з}\right)\left\{N_{B}+\left\lfloor\sum_{j=1}^{f} E_{n c j} N_{n c j}+E_{n p m j} N_{n p m j}+\left(E_{n p c j}^{B}-\right.\right.\right. \\
& \left.\left.-1) N_{n p c j}^{B}+\left(E_{n p c j}^{n c}-1\right) N_{n p c j}^{n c}+\left(E_{\text {збј }}-1\right) N_{\text {збј }}\right\rfloor\right\},
\end{aligned}
$$

де $f$ - кількість підходів до залізничного вузла.

При розташуванні станцій за схемами 16,1 , 1 е слід окремо визначити $N_{\text {ппс }}$ від розв'язок до ПС і від розв'язок до СС.

$$
\begin{aligned}
& N_{\Pi \Pi C}^{\Pi C}=\left(1-\alpha_{\text {pes }}\right)\left\{N_{n C}+\sum_{j=1}^{f}\left[\left(E_{W B j}-1\right) N_{W B j}+\left(E_{\Pi P M j}-1\right) N_{\Pi P M j}\right]\right\}, \\
& N_{\Pi M C}^{B}=\left(1-\alpha_{\text {pes }}\right)\left\{N_{B}+\sum_{j=1}^{f}\left[\left(E_{\Pi M P C j}-1\right) N_{\Pi M C j}+\left(E_{36 j}-1\right) N_{36 j}\right]\right\} .
\end{aligned}
$$

При цьому слід враховувати, що при розташуванні станцій за схемами 1 а та 16 коефіцієнт резерву необхідно приймати 0,2 , а за іншими схемами -0,15. Якщо до вузла примикають підходи 3 різною кількістю колій, то $\alpha_{\text {pes }}=0,15$.

В окремих випадках може застосовуватися схема $1 г$, при цьому від ПС до розв'язки П5 слід визначати $N_{\text {Ппс за }}$ формулою (3); від П5 до П6 - за формулою (4), і від СС до П5 та П6 - за формулою (5).

Після розрахунку $\mathrm{K}_{\text {зпс }} \mathrm{y}$ кожному напрямку слід виконувати аналіз результатів і робити відповідні висновки щодо необхідної кількості головних колій, при цьому необхідно врахувати вимоги ПТЕ [4] щодо визначення інтенсивного та особливо інтенсивного руху на одноколійних та двоколійних лініях.

Число головних колій між основними станціями або між розв'язкою та певною станцією пропонується визначити:

$$
m_{\mathrm{rK}}=\left(\mathrm{K}_{\text {smc }}^{I}+\mathrm{K}_{\text {smc }}^{I I}\right) /\left(1-\alpha_{\text {pes }}\right),
$$

де $\mathrm{K}_{\text {зпс }}^{I}, \mathrm{~K}_{\text {зпс }}^{I I}-$ коефіцієнт заповнення пропускної спроможності головної колії відповідно у непарному та парному напрямку.

Якщо для схеми 1а $m_{\text {гк }} \leq 0,8$, то між ПС і СС проектується одноколійна лінія; при $m_{\text {гк }}=0,81 \ldots 1,6$ - дві головні колії двосторонньої дії; при $m_{\text {гк }} \leq 1,6$ та особливо інтенсивному русі поїздів двоколійна лінія зі спеціалізацією колій за напрямком руху.

Для схеми 1в при $m_{\text {гк }} \leq 1,7$ між ПС і СС проектується двоколійна лінія; при $m_{\text {гк }}=1,71 \ldots 2,51$ та інтенсивному русі поїздів слід проектувати третю головну колію двосторонньої дії, а при $m_{\text {гк }}>2,51$ та при особливо інтенсивному русі - дві двоколійні лінії, з яких одна пара головних колій спеціалізується для пасажирського, а інша - для вантажного руху, при цьому на примикаючих підходах слід застосовувати частотне автоблокування.

Для схеми 16 висновки такі ж, як і для схеми 1a, тільки відповідна кількість головних колій повинна укладатися від розв'язок до ПС та до СС. 
Якщо для схеми 1д i 1 e $m_{\text {тк }} \leq 1,7$, то між розв'язками та ПС або СС проектуються двоколійні лінії; при $m_{\text {гк }}=1,71 \ldots 2,51 \quad$ та інтенсивному пасажирському русі між розв'язками та ПС проектується третя головна колія двосторонньої дії (як правило, примикаючи підходи із В та $\Gamma$ - одноколійні), а між розв'язками та СC проектується третя головна колія, що спеціалізується для руху вантажних поїздів у переважному напрямку; а при $m_{\text {гк }}>2,51$ та особливо інтенсивному русі - між розв'язками і ПС слід укладати дві двоколійні лінії, з яких одна пара головних колій призначена для дальних пасажирських, a інша - для місцевих пасажирських та приміських поїздів; а між розв'язками i $\mathrm{CC}$ проектуються дві головні колії для руху вантажних поїздів у переважному, та дві у непереважному напрямку (як правило, примикаючи підходи із В і Г - двоколійні ).
Для схеми 1г кількість головних колій між ПС і розв'язкою П5 проектується як і для схеми 1в; між розв'язками П5 і П6 - як і для схеми 1е між ПС і розв'язками, а між П5 - СС - П6 - як для схеми 1е між $\Pi 10-\mathrm{CC}-\Pi 11$.

Висновки. Технічне забезпечення пропускної спроможності внутрішньовузлових ходів може здійснюватися за рахунок впровадження як організаційнотехнологічних, так i реконструктивних заходів, але в кожному випадку їм повинно відповідати необхідне число головних колій між основними станціями вузла, яке пропонується визначити згідно 3 розробленою методикою.

У подальших дослідженнях передбачається визначення впливу завантаження розв'язок на підходах до вузла як на пропускну спроможність, так i на кількість головних та з'єднувальних колій у межах розв'язок та вузла.

\section{Список літератури}

1. Інструкція 3 розрахунку наявної пропускної спроможності залізниць України [Текст]: ЦД - 0036. - К.: Транспорт України, 2012. - 376 с.

2. Крячко, В.І. Проектування сортувальної станції та залізничного вузла [Текст] / В.І. Крячко // Навч. посіб. - Харків: ХарДАЗТ, 1999. - 66 с.

3. ДБН В.2.3-19-2008. Споруди транспорту. Залізниці колії 1520 мм. Норми проектування [Текст]. - К. : Мінрегіонбуд, 2008. - 122 с.

4. Правила технічної експлуатації залізниць України [Текст]. - К.: Транспорт України, 2003. -238 c.

Ключові слова: внутрішньовузлові ходи, пропускна спроможність, коефіцієнт резерву, залізничний вузол, розв'язка.

\section{Анотаціï}

Запропонована методика визначення пропускної спроможності внутрішньовузлових ходів і кількості головних колій на них залежно від взаємного розташування основних станцій у вузлі та схеми пропускання поїздів різних категорій по відношенню до них.

Предложена методика определения пропускной способности внутриузловых ходов и количества главных путей на них в зависимости от взаимного расположения основных станций в узле и схемы пропуска поездов различных категорий по отношению к ним. 
Offered method of determination of carrying capacity of into a knot motions and number of main ways on them depending on the mutual location of the basic stations in a knot and chart of admission of trains of different categories to in relation to by him. 